\title{
Maintenance and Recovery Plan for Western Spiderwort in Alberta 2005-2010
}
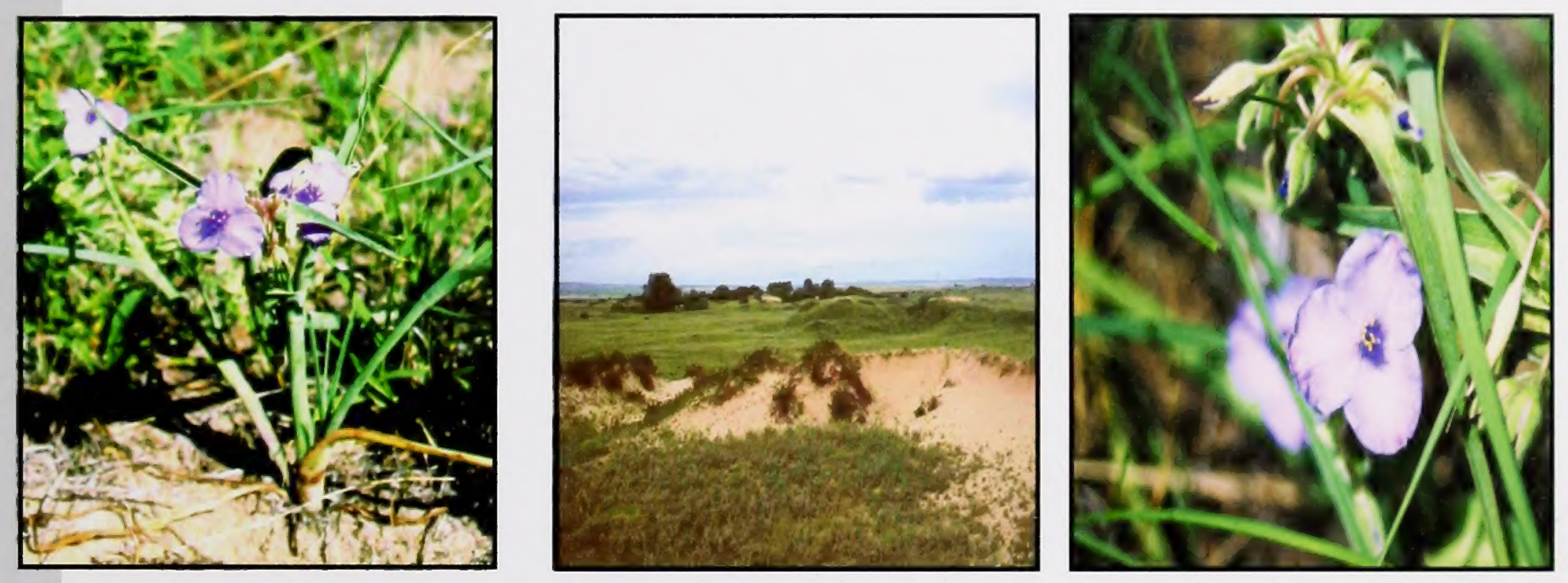

Alberta Species at Risk Recovery Plan No. 9

Alberla 



\section{Maintenance and Recovery Plan for Western Spiderwort in Alberta 2005-2010}

Prepared by:

The Alberta Western Spiderwort Recovery Team

Joel Nicholson (Team Chair), Sustainable Resource Development, Fish and Wildlife Division Barry Biesterfeldt, Rancher

Joanne Golden, Alberta Native Plant Council

Joyce Gould, Alberta Community Development, Parks and Protected Areas Division

Lyndon Haugan, Rancher

Terry Hood, Alberta Sustainable Resource Development, Public Lands and Forests Division

Dan Johnson, University of Lethbridge

Kelley Kissner, Alberta Sustainable Resource Development, Fish and Wildlife Division Paul Weeks, Rancher

Robert Weeks, Rancher

December 2005

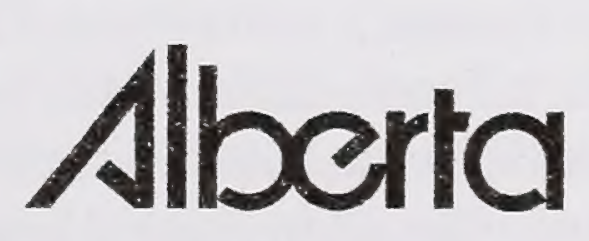


Publication No.: I/232

ISBN: 0-7785-4517-2 (Printed Edition)

ISBN: 0-7785-4518-0 (On-line Edition)

ISSN: $1702-4897$ (Printed Edition)

ISSN: 1702-4900 (On-line Edition)

Cover photos:

Western spiderwort plant - Sue Peters

Sand dunes - Joyce Gould

Western spiderwort plant - Joel Nicholson

For copies of this report, contact:

Information Centre - Publications

Alberta Sustainable Resource Development

Main Floor, Great West Life Building

9920 - 108 Street

Edmonton, Alberta, Canada T5K 2M4

Telephone: (780) 422-2079

\section{OR}

Visit the Alberta Species at Risk Program web site at:

http://www3.gov.ab.ca/srd/fw/speciesatrisk/

This publication may be cited as:

Alberta Western Spiderwort Recovery Team. 2005. Maintenance and recovery plan for western spiderwort in Alberta 2005-2010. Alberta Sustainable Resource Development, Fish and Wildlife Division, Alberta Species at Risk Recovery Plan No. 9. Edmonton, AB. 18 pp. 


\section{PREFACE}

Albertans are fortunate to share their province with a diverse variety of wild species. Populations of most species of plants and animals are healthy and secure. However, a small number of species are either naturally rare or are now imperilled because of human activities. Recovery plans establish a basis for cooperation among government and stakeholders to ensure these species and populations are restored or maintained for future generations.

Alberta's commitment to the Accord for the Protection of Species at Risk and to the National Framework for the Conservation of Species at Risk, combined with requirements established under Alberta's Wildlife Act and the federal Species at Risk Act, has resulted in the development of a provincial recovery program. The overall goal of the recovery program is to restore species identified as Threatened or Endangered to viable, naturally self-sustaining populations within Alberta.

Alberta species at risk recovery plans are prepared under the supervision of the Fish and Wildlife Division, Alberta Sustainable Resource Development. These recovery plans are prepared by recovery teams composed of a variety of stakeholders including conservation organizations, industry, landowners, resource users, universities, government agencies and others. Membership is by invitation from the Director of Wildlife Management, and includes representation from the diversity of interests unique to each species and circumstance. Conservation and management of these species continues during preparation of the recovery plan.

Recovery plans include three main sections: background information that highlights the species' biology, population trends and threats; a recovery section that outlines goals, objectives, and strategies to address the threats; and an action plan that profiles priority actions required to maintain or restore the Threatened or Endangered species.

These plans are provided by the recovery team as advice to the Minister of Sustainable Resource Development (the Minister; the Department) and to all Albertans. The Department, other provincial departments, as appropriate, and Alberta's Endangered Species Conservation Committee review draft recovery plans, and provide recommendations to the Minister. In addition, an opportunity for review by the public is provided.

Approved plans are a summary of the Department's commitment to work with involved stakeholders to coordinate and implement conservation actions necessary to restore or maintain these species. Recovery plans are "living" documents and are revised as conditions change or circumstances warrant. Implementation of each recovery plan is subject to the availability of resources, from within and from outside government.

The Maintenance and Recovery Plan for Western Spiderwort in Alberta 2005-2010 was reviewed by the Endangered Species Conservation Committee in June 2005. The committee subsequently recommended to the Minister that the plan be approved as written, and implemented. On December 16, 2005, the Minister approved the recovery plan and directed the Department to work toward its effective implementation. 
PREFACE

ACKNOWLEDGEMENTS V

EXECUTIVE SUMMARY vii

1.0 INTRODUCTION 1

1.1 Provincial and Federal Status

1.2 Recovery Team

2.0 SPECIES' BIOLOGY

2.1 Life History and Adaptations 2

2.2 Habitat 2

2.3 Population Distribution and Trends in Alberta 3

3.0 THREATS

3.1 Conversion of Native Habitat 5

3.2 Dune Stabilization 5

3.3 Petroleum Exploration and Development 5

3.4 Grazing by Cattle 5

3.5 Invasive Species 6

4.0 KNOWLEDGE GAPS AND INFORMATION NEEDS 6

Habitat Requirements 6

Effects of Precipitation 6

Grazing Studies 6

Pollination Biology 7

Seedbank 7

Invasive species

Genetic Studies 7

5.0 RECOVERY STRATEGY

5.1 Biological and Technical Feasibility of Recovery

5.2 Guiding Principles 8

5.3 Recovery Goal 8

5.4 Recovery Objectives 8

5.5 Strategies for Recovery

5.5.1 Population Conservation and Management 9

5.5.2 Habitat Conservation and Management 
5.5.3 Information and Education

5.5.4 Research

5.5.5 Resourcing

5.5.6 Legislation

5.5.7 Plan Management and Administration

6.0 RECOVERY ACTION PLAN

6.1 Population Conservation and Management 10

6.2 Habitat Conservation and Management 10

6.3 Information and Education 11

6.4 Research 12

6.5 Resource Acquisition 13

6.6 Legislation 13

6.7 Plan Management and Administration 13

7.0 TIMETABLE FOR IMPLEMENTATION AND SCHEDULE OF COSTS 14

8.0 SOCIO-ECONOMIC CONSIDERATIONS 15 9.0 PLAN REVIEW AND AMENDMENT 15 10.0 LITERATURE CITED

\section{List of Figures}

Figure 1. The species range in North America and the location of the western spiderwort population in southern Alberta.

\section{List of Tables}

Table 1: Results of Western Spiderwort Surveys conducted 1986 - 2003. 4 


\section{ACKNOWLEDGEMENTS}

The Alberta Western Spiderwort Recovery Team would like to thank Dr. Norm Kenkel (University of Manitoba) for providing literature on the Manitoba population of western spiderwort for use in the planning process. The recovery team would also like to thank Dr. Albert Finnamore (Provincial Museum of Alberta) and Keith Roney (Royal Saskatchewan Museum) for providing information on pollinators of western spiderwort.

Funding for the preparation of the recovery plan was provided by all member organizations and individuals and the Species at Risk Program of Alberta Sustainable Resource Development. In addition, Alberta Community Development and the University of Lethbridge provided in-kind resources for undertaking preliminary surveys of spiderwort and potential pollinators during 2004. 


\section{EXECUTIVE SUMMARY}

Western spiderwort (Tradescantia occidentalis) is a herbaceous perennial flowering plant native to the Canadian prairies. Spiderwort plants have a slender stem and long, grasslike leaves. Blue or purple flowers are produced from clusters of buds that hang from stalks at the top of the stem.

In September 2001, the Minister of Sustainable Resource Development approved the listing of western spiderwort as Endangered in Alberta. This designation was based on the Alberta population's small size, its occurrence at only one site, and its geographic separation from other spiderwort populations in Canada and the United States. In November 2002, the Committee on the Status of Endangered Wildlife in Canada (COSEWIC) designated western spiderwort as Threatened in Canada due to its limited occurrence and distribution in Canada. In addition to the population in Alberta, spiderwort also occurs at one location in Saskatchewan and three locations in Manitoba.

The goal of this maintenance and recovery plan is to maintain the existing habitat and distribution of western spiderwort and to maintain a naturally, self-sustaining population of western spiderwort in Alberta. The specific strategies used to attain these goals are: (1) conservation and management of the western spiderwort population to allow for the persistence of the species in the province; (2) conservation and management of habitat essential to maintain western spiderwort; (3) provision of information and educational materials to the public and stakeholders to promote the conservation of western spiderwort; (4) research to elucidate aspects of the life history of spiderwort, its population dynamics, and its habitat and habitat management requirements that are necessary for maintenance of the species; (5) acquisition of resources needed to implement the recovery plan, and; (6) development of policies or regulations to protect western spiderwort and its habitat.

It is expected that implementation of activities to conserve western spiderwort, combined with stakeholder cooperation and commitment, will allow for the long-term persistence of spiderwort in Alberta. 
Digitized by the Internet Archive in 2016 


\subsection{INTRODUCTION}

\subsection{Provincial and Federal Status}

In September 2001, the Minister of Sustainable Resource Development approred the listing of western spiderwort (Tradescantia occidentalis (Britt.) Smyth) as Endangered in Alberta on the recommendation of the Alberta Endangered Species Conservation Committee (ESCC). This designation was based on the small size of the population, its occurrence at only one site, and its geographic separation from other spiderwort populations in Canada and the United States. The Initial Conservation Action Statement put forth by the ESCC, and approved by the Minister, specified that a recovery plan should be developed in order to set goals, objectives, strategies and management actions necessary to guide the recovery of this species during the next five years. The action statement also specified that management should focus on the identification and conservation of the existing population to prevent loss from managed activities (c.g., industry, agriculture, and recreation), rather than the creation or reintroduction of new populations. In November 2002, the Committee on the Status of Endangered Wildlife in Canada (COSEWIC) designated western spiderwort as Threatened in Canada due to its limited occurrence and distribution in Canada (COSEWIC 2002, 2004). In addition to the population in Alberta, spiderwort also occurs at one location in Saskatchewan and three locations in Manitoba (Hrapko 1989, Godwin and Thorpe 1991, Smith and Bradley 1992, Goulet and Kenkel 1997, Hughes 2001, Smith 2002). A national recovery strategy(ies) for endangered and threatened plants across the Prairie Provinces is currently under development.

\subsection{Recovery Team}

At the direction of the Minister of Sustainable Resource Development, the Alberta Western Spiderwort Recovery Team was initiated in 2003 by the Director of Wildlife Management. The teamís primary responsibility is to facilitate and coordinate the conservation and recor ery of western spiderwort in Alberta. The team provides expert advice to the Minister (or his delegate) on all matters relating to the management of western spiderwort in Alberta. The tcam is also responsible for writing, updating, and guiding the implementation of the provincial recovery plan. Team members do not typically implement recovery actions directly, although team members and the organizations they represent will participate in the recovery actions. Whenerer possible, the team will encourage and facilitate the involvement of all interested parties in the recovery of western spiderwort in Alberta, and will annually report on the progress of the recovery program.

Membership of the recovery team attempts to include the best representation of parties likely to affect or to be affected by recovery actions and currently consists of the following members: Alberta Sustainable Resource Development (Fish and Wildlife Division and Public Lands and Forests Division), Alberta Community Development (Parks and Protected Areas Division, Alberta Natural Heritage Information Centre (ANHIC)), Alberta Native Plant Council, University of Lethbridge, and several members of the local ranching community. 


\subsection{SPECIES BIOLOGY}

\subsection{Life History and Adaptations}

Western spiderwort is a herbaceous perennial flowering plant native to the North American prairies. Spiderwort derives its name from the sticky, stringy substance that is secreted from its stem when broken. When exposed to air, this substance hardens into cobweb-like threads (Jones and Luchsinger 1986, Kershaw et al. 2001).

Spiderwort plants have a slender stem $(10$ to $50 \mathrm{~cm})$, with long, grasslike leaves $(10$ to $30 \mathrm{~cm})$ extending from the stem (Goulet and Kenkel 1997, Kershaw et al. 2001). Flowers typically appear in late June and early July, and are produced from clusters of buds that hang from stalks at the top of the stem (Smith 2001, Peters 2003b). One or two flowers open at a time and each flower lasts only one day (Smith 2001). Flowers are blue or purple with bright yellow anthers (Smith and Bradley 1990, Kershaw et al. 2001, Smith 2001). Above ground portions of the plant die-back after flowering, but some regrowth may occur in late summer (Kershaw et al. 2001).

Spiderwort propagates through the production of seeds and also through roots that develop from the stem (Hohn 1994, Smith and Bradley 1990). Sweat bees (order Hymenoptera, family Halictidae) are common pollinators of western spiderwort in Manitoba (Kershaw et al. 2001). Other species of bees have been associated with the genus, suggesting that spiderwort may have a wide range of pollinators (A. Finnamore, pers. comm.). In Alberta, bees and flies have been observed to visit western spiderwort flowers (Peters 2003b, D. Johnson and J. Gould, pers. comms.). The role of self-pollination is not understood. Non-fertilized flowers form capsulelike structures that are small and round in shape, whereas fertilized flowers form oval-shaped capsules (Hrapko 1989, Kershaw et al. 2001, Smith 2001). Mature capsules are generally produced by mid to late July (Kershaw et al. 2001). Seeds have low dispersal properties and generally fall near the parent plants, resulting in the tendency for plants to exhibit a clumped distribution.

\subsection{Habitat Requirements and Essential Habitat}

Western spiderwort occurs in the Dry Mixed Grass Subregion of Alberta (ANHIC 2002). Within this region, this species typically occurs in areas with sandy soils, particularly active or partially active sand dunes and sparsely vegetated areas around dunes (Wallis and Wershler 1988, Smith and Bradley 1992, Kershaw et al. 2001, Smith 2001, Peters 2003a). Spiderwort has also been found growing on grassy slopes and in low areas among dunes growing near drought-resistant grasses, shrubs, and trees (Peters 2003a, 2003b). In Manitoba, western spiderwort has been found growing in meadows and shaded habitat among low growing shrubs (Goulet and Kenkel 1997). Details on other vegetation associated with the Alberta population of western spiderwort can be found in Coupland (1987), Hrapko (1989), Smith (2001), and Peters (2003a). Although the general habitat requirements of the species are known, further investigation will be required to establish its specific habitat requirements (e.g., level of tolerance to vegetation/stabilization) in order to determine essential habitat for this species. 


\subsection{Population Distribution and Trends in Alberta}

Western spiderwort was discovered in Alberta in 1986 in the northern portion of the Pakowki Lake Sandhills west of the town of Manyberries (Figure 1). Another possible occurrence at Whiskey Gap was never confirmed to be spiderwort (J. D. Johnson unpubl. data). Additional surveys at this location and at other locations with sand dune habitat in Alberta, including southern portions of the Pakowki Lake Sandhills, Lost River, Purple Springs, Turin, and Hilda, have not revealed additional populations of western spiderwort (Wallis and Wershler 1988, Smith 2002, Peters 2003a, 2003b).

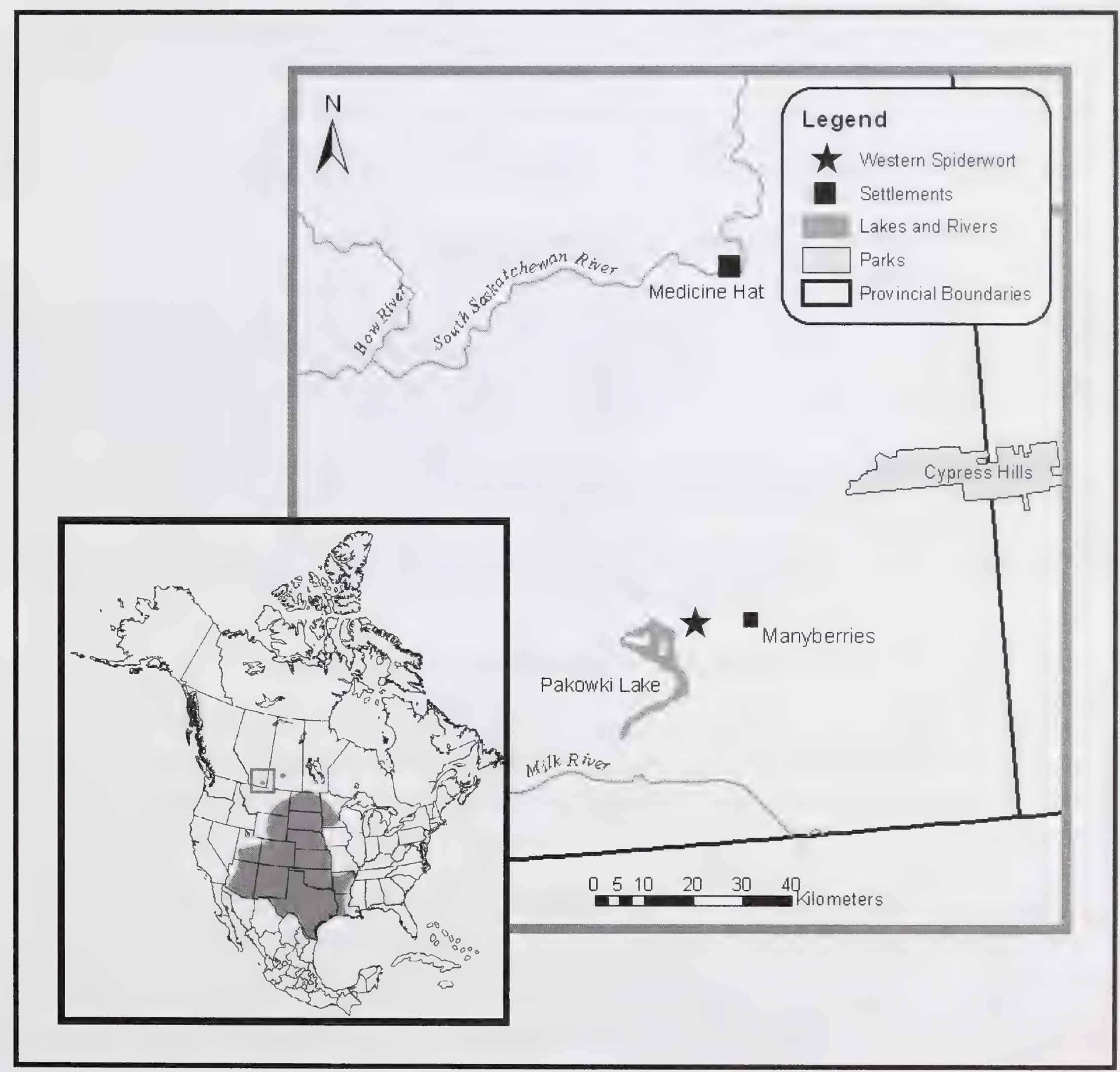

Figure 1. The species range in North America and the location of the western spiderwort population in southern Alberta. (North American range map is from Smith (2001)). 
The Alberta population of western spiderwort is limited in distribution to an area of approximately $2.22 \mathrm{~km}^{2}$ (Peters 2003a, 2003b). Most of this area is public land under grazing disposition, but some of this area is private land. The single population of spiderwort in the Pakowki Lake Sandhills is divided into 21 distinct patches (Peters 2003a, 2003b). One very small additional patch that was surveyed for many years previously was not observed in 2003 (Peters 2003b).

Population trends for western spiderwort are difficult to assess because of its restricted distribution, its sensitivity to moisture levels, and the lack of standardized surveys of this species since its discovery in Alberta (Peters 2003a). Although surveys have been conducted sporadically since 1986 there has been no standardization in the amount of area that has been surveyed. Consequently, it is difficult to determine whether variation in numbers of plants across years reflects true population fluctuations or is an artefact of differences in the amount of area surveyed (see table 1 below).

Table 1: Results of Western Spiderwort Surveys conducted 1986 - 2003.

\begin{tabular}{|l|l|l|l|}
\hline $\begin{array}{l}\text { Survey } \\
\text { year }\end{array}$ & $\begin{array}{l}\text { General Precipitation } \\
\text { Conditions }\end{array}$ & $\begin{array}{l}\text { Number of Individuals } \\
\text { Counted }\end{array}$ & Source \\
\hline 1986 & Average & 50 & Hrapko 1989 \\
\hline 1987 & Dry & 30 & Hrapko 1989 \\
\hline 1990 & Wet & 210 & Smith and Bradley 1992 \\
\hline 1999 & Dry & 27 & $\begin{array}{l}\text { J. Gould and P. Cotterill } \\
\text { unpubl. data }\end{array}$ \\
\hline 2001 & Dry & 7 & Smith 2001 \\
\hline 2002 & Very Wet & 7,450 & Peters 2003a \\
\hline 2003 & Wet & 7,700 & Peters 2003b \\
\hline
\end{tabular}

Western Spiderwort survey results show a high amount of variability. In 1986, 50 plants were recorded, whereas in 1987, a drier year, only 30 plants were counted (Hrapko 1989). In 1990, a wet year, 210 plants were recorded (Smith and Bradley 1992). In 1999 and 2001, both dry years, 27 (J. Gould and P. Cotterill unpubl. data) and 7 (Smith 2001) plants were recorded, respectively. In 2002, a year with extremely heavy precipitation, population size was estimated to be 7450 plants (Peters 2003a). This survey established that a substantially larger population appears to exist and that optimal moisture conditions allow for increased propagation. In 2003, a year with high precipitation during the spring, the population size was estimated to be 7700 plants (Peters 2003b). This survey suggests that the abundance of spiderwort in 2002 did not result from an opportunistic, short-lived expansion in a year of optimal growing conditions and that this species may be able to persist in high numbers under relatively moist conditions (Peters 2003b). Additional documentation of high plant numbers and annual precipitation records is needed to confirm this hypothesis. 


\subsection{THREATS}

The Alberta population of western spiderwort is highly vulnerable to extirpation due to its limited occurrence and distribution and its isolation from other populations in Canada and the United States. Spiderwort occurs over an extremely small area (ca. $2.2 \mathrm{~km}^{2}$ ) (Peters $2003 \mathrm{a}$. 2003b). The persistence of western spiderwort in Alberta largely depends on maintaining the integrity of habitat for this species. Currently, there is no protection in the Wildlife Act for western spiderwort or its habitat; however, regulations are currently under development for the protection of endangered and threatened plants.

\section{$\underline{3.1 \text { Conversion of Native Habitat }}$}

Conversion of native prairie (e.g., cultivation, tame pasture) results in direct loss of habitat for many prairie species. Much of the range of western spiderwort in Alberta is on public land under grazing disposition and has a lower risk of conversion, but some is on private land. Conversion of native habitat within the range of this species in Alberta would lead to loss of individual plants and habitat for this species.

\subsection{Dune Stabilization}

Western spiderwort is limited to sand dune habitat but seems to tolerate the presence of some vegetation given that it has been found on partially-stabilized grassy slopes and growing adjacent to shrubs (Peters 2003a, 2003b). However, complete stabilization of dunes or adjacent sandy areas would result in loss of habitat for western spiderwort.

\subsection{Petroleum Exploration and Development}

Petroleum exploration (e.g., seismic) and development (e.g. natural gas well sites) may remove or alter habitat for this species or result in the direct removal of plants.

\section{$\underline{3.4 \text { Grazing }}$}

In Alberta, spiderwort has persisted under grazing regimes for many years. There has been no research on optimum levels of grazing to maintain western spiderwort and its habitat. However, light to moderate grazing by livestock may benefit spiderwort by helping to destabilize vegetation communities in and around sand dunes. Another possible benefit of grazing could be seed dispersal by livestock, if seeds are able to pass intact through a cow's digestive tract (Goulet and Kenkel 1997). Although there may be benefits to grazing, over-grazing, direct grazing or trampling of spiderwort plants, and heavy disturbance in sand dune habitat may threaten the persistence of this species (Hohn 1994, Goulet and Kenkel 1997). In Manitoba, cattle have been observed to graze spiderwort plants, particularly when in full flower (Goulet and Kenkel 1997). Peters $(2003 \mathrm{a}, 2003 \mathrm{~b})$ reported that, on average, about $15 \%$ of spiderwort plants in patches that were examined closely had some evidence of grazing (range in 2002: 0-44\%, range in 2003 0$37 \%$ ), but this appeared to be mainly from native ungulates. Grazed plants are more difficult to see because of the lack of flowers, so these percentages may be underestimated. Spiderwort appears to have some capacity to recover from grazing if plants are not grazed to the ground; 
although plants may not set seed in the year they are grazed (Goulet and Kenkel 1997). Reduced seed production due to long-term grazing of flowers could eventually result in a decrease in overall population size (Goulet and Kenkel 1997).

\section{$\underline{3.5 \text { Invasive Species }}$}

Invasion by introduced species threatens a variety of native plant species. Invasion by leafy spurge (Euphorbia esula) has resulted in the elimination of habitat for western spiderwort in all Canadian locations other than Alberta (Smith and Bradley 1992, Goulet and Kenkel 1997). This effect appears to occur through competition for habitat, rather than through any adverse effects of spurge on the fecundity or phenology of spiderwort (Goulet and Kenkel 1997). Leafy spurge occurs sporadically in Alberta and has not yet been recorded in the Pakowki Lake Sandhills (Smith 2001, Peters 2003b), but could threaten this species in the future. Other non-native species could also limit habitat for western spiderwort.

\subsection{KNOWLEDGE GAPS AND RESEARCH NEEDS}

Several areas of research (identified in order of priority) would help elucidate aspects of western spiderwort's biology. These research items are relevant to the implementation of specific activities outlined in the recovery plan, and are relevant to the species status in Alberta and to the long-term conservation and management of this species.

\section{Habitat Requirements}

Research is needed to determine the specific habitat requirements of western spiderwort. Western spiderwort appears to prefer sand dune habitat but has also been found growing in more stabilized areas. Studies are needed to establish the species' tolerance for varying levels (or types) of vegetation and the effectiveness of different measures to prevent vegetation encroachment (Peters 2003a, 2003b). This research is necessary to help establish essential habitat for this species and to aid in managing habitat for this species.

\section{Effects of Precipitation}

Research is needed to determine how precipitation influences fluctuations in population size. Furthermore, understanding the relationship between natural fluctuations in precipitation (and hence, spiderwort populations) and vegetation encroachment in sandy areas is important to understanding the long-term sustainability of Alberta's spiderwort population. Research is also required on the role of moisture on plant life history, including flowering times, seed production, and seed germination and viability. These studies will aid in interpreting past and future population trends of this species.

\section{Grazing Studies}

Studies are needed on how variation in grazing regimes as currently practiced by landowners and leaseholders influences plant life history (e.g., seed set) and habitat (e.g., stabilization or destabilization of dunes). Grazing regimes that should be investigated include stocking rates and timing and duration of grazing. This information is needed to help develop best management practices (BMP's) for livestock grazing in areas supporting spiderwort populations. Research is 
also needed to determine the relative contribution of grazing by native ungulates to determine whether activities to limit grazing by native ungulates are required.

\section{Pollination Biology}

Little information exists on the specific pollinators of the Alberta population and the role of pollinators in population dynamics of this species. Studies are needed on types and range of pollinators in order to determine whether the distribution and abundance of this species might be limited by the distribution and abundance of its pollinators.

$\underline{\text { Seedbank }}$

Research is needed to determine the role of the seedbank in maintaining this species, including germination rates and how long seeds remain viable (Peters 2003a, 2003b). Although this species appears to be relatively drought tolerant over the short-term, it is unknown whether the seedbank will be able to maintain the population following prolonged periods of drought.

\section{Invasive species}

Surveys are needed to monitor for invasive species (e.g., leafy spurge) in spiderwort habitat. If invasive species are identified, research will be required to determine methods of eradication that won't negatively impact western spiderwort.

\section{Genetic Studies}

Genetic studies are required to determine the genetic relationship between the Alberta population and the Saskatchewan and U.S. populations (Peters 2003a, 2003b). This information is relevant to future status assessments of this species because it would establish whether isolation from other Canadian and U.S. populations has resulted in this species being considered distinct (i.e., separate subspecies or species) and whether the Alberta population is highly inbred.

\subsection{RECOVERY STRATEGY}

\section{$\underline{5.1 \text { Biological and Technical Feasibility of Recovery }}$}

The primary reasons for listing western spiderwort as Endangered are its small population size, its location at only one site, and its isolation from other populations in Canada and the United States. The specific habitat requirements of this species (sandy soils, sandhills) and its limited dispersal ability make it unlikely that this species will spread to new locations in Alberta or become more closely connected to other populations in Canada or the United States. Despite these limitations, there is good potential to maintain this species in Alberta. The Alberta population of western spiderwort has persisted in Alberta for at least two decades, since it was discovered in 1986, despite large fluctuations in population size and the species has likely been on the landscape for much longer. Recent surveys (2002 and 2003) indicate much larger population sizes than had previously been recorded. The species appears to have some resistance to drought and grazing given its persistence under a variety of moisture conditions and grazing regimes. Careful and cooperative management of spiderwort habitat by all stakeholders will be key to the persistence of this species in Alberta. It is the belief of this team that a viable population of spiderwort can be maintained while allowing for compatible land use activities. 


\subsection{Guiding Principles}

The conservation and management of western spiderwort in Alberta will be guided by the following principles:

- The conservation of western spiderwort is possible and it is important to maintain this unique prairie species.

- Loss of habitat for western spiderwort is unacceptable and preventable.

- The recovery plan is based on the assumption that all land users and managers within the range of western spiderwort, including all affected branches of government, share responsibility for and are committed to conserving western spiderwort and key habitat supporting this species. Commitment and action by all of these parties will be critical to conservation.

- A cooperative approach with land managers, landowners, industry and other agencies is essential to the success of this plan. This includes shared stewardship, compatible land use and local commitment to management initiatives.

- Landowners and lessees will not be adversely affected by the costs associated with maintaining or enhancing habitat for western spiderwort.

- Knowledge gaps will be identified and will be communicated in the recovery plan.

- Management actions will use tools resulting in the most immediate benefit to western spiderwort and will be based on the best information available. Implementation will not be delayed because of lack of specific supporting information.

- Recovery actions will focus on achievable initiatives and on those initiatives deemed most effective in conserving western spiderwort in Alberta.

- Recovery actions will embrace an ecosystem (holistic) approach to management.

- The recovery process will be guided by the concept of adaptive management, whereby specific actions are implemented, evaluated, and revised on an iterative basis to ultimately improve the outcome.

\section{$\underline{5.3 \text { Recovery Goal }}$}

The goal of the recovery plan is to maintain the existing habitat and distribution of western spiderwort and to maintain a naturally, self-sustaining population of western spiderwort in Alberta.

\subsection{Recovery Objectives}

The specific objectives that will lead to long-term maintenance of western spiderwort are:

1. Maintain the population and distribution of western spiderwort by ensuring no loss of habitat quality or quantity on public land from human-caused disturbances.

2. Maintain the population and distribution of western spiderwort by encouraging voluntary stewardship on privately-owned lands occupied by western spiderwort.

3. Understand population dynamics and trends of western spiderwort to aid in the long-term conservation of this species. 
The Maintenance and Recovery Plan for Western Spiderwort in Alberta will serve for an initial period of five years (2005-2010), and consists of the following strategies that will be pursued concurrently:

\subsubsection{Population Conservation and Management}

1. Establish monitoring protocols and monitor population size, trend, dynamics and distribution of the Alberta population of western spiderwort.

\subsubsection{Habitat Conservation and Management}

1. Identify essential habitat for western spiderwort.

2. Identify risks to essential habitat for western spiderwort and work cooperatively with landowners, lessees, land managers, industry, and other stakeholders to undertake management activities to eliminate or mitigate these risks.

3. Communicate and encourage general principles for range/habitat management that are compatible with the maintenance of western spiderwort and its habitat.

\subsubsection{Information and Education}

1. Communicate and promote understanding of the recovery plan to the public and stakeholders.

2. Increase awareness of landowners, leaseholders, and of the general public of the requirements to conserve western spiderwort in Alberta.

\subsubsection{Research}

1. Highlight key areas of study that will inform and facilitate the conservation of western spiderwort, encourage these studies to be initiated, and support researchers in their efforts to secure funding to undertake these investigations.

\subsubsection{Resourcing}

1. Secure logistical, financial, and in-kind support to implement the recovery plan.

\subsubsection{Legislation}

1. Identify, and act upon, any provincial government legislative changes that may be necessary for the long-term maintenance of western spiderwort.

\subsubsection{Plan Management and Administration}

1. Monitor and evaluate the effectiveness of conservation activities for western spiderwort.

2. Ensure that new information on western spiderwort is made available to the recovery team and to resource managers.

3. Ensure that recovery actions for western spiderwort complement, where possible, the conservation of other provincially or federally listed species. 


\subsection{ACTION PLAN}

\subsection{Population Conservation and Management}

1. Alberta Fish and Wildlife Division, ANHIC, Canadian Wildlife Service, or researchers from conservation organizations and universities will develop a standardized survey protocol for monitoring western spiderwort. This will support long-term monitoring of this species in Alberta and will provide information to the recovery team. The Alberta Western Spiderwort Recovery Team recommends this initiative be undertaken in year 1.

2. Researchers from government agencies, non-government organizations, or universities will conduct annual standardized surveys to monitor the distribution, abundance, and population trends of western spiderwort in Alberta, including monitoring sites currently occupied by western spiderwort and sites identified as providing favourable habitat for western spiderwort.

3. In association with annual spiderwort surveys, researchers from government agencies, nongovernment agencies, or universities will conduct surveys for pollinators of western spiderwort and for invasive species (e.g., leafy spurge).

4. Government agencies and non-government organizations, in association with landowners and lessees, will survey for invasive species in habitat containing and adjacent to western spiderwort and, if identified, will recommend and/or implement measures to remove or reduce their presence.

\subsection{Habitat Conservation and Management}

1. Pending research on the specific habitat requirements of this species, government agencies, with the assistance of appropriate non-government organizations and/or universities will identify and map essential habitat for western spiderwort. These maps will be distributed to resource managers (e.g., Alberta Fish and Wildlife Division, Alberta Public Lands and Forests Division, ANHIC, Alberta Energy and Utilities Board) and should be used as the basis for prioritizing survey locations for this species and for permitting/mitigating land use activities and sale or trade of public land in these areas. The Alberta Western Spiderwort Recovery Team recommends this initiative be undertaken in year 3 .

2. Alberta Fish and Wildlife Division will make application to Alberta Public Lands and Forests Division to place protective notations, consultative notations, or other protective designations on all quarter sections of public land with naturally occurring populations of western spiderwort in order to limit disturbance to the species and its habitat. Once essential habitat has been identified, notations should then be placed on all quarter sections of public land identified as essential habitat for this species. The Alberta Western Spiderwort Recovery Team recommends that this initiative be undertaken in year 1 and be updated as necessary.

3. Researchers from government agencies, non-government organizations, or universities will undertake a program to monitor habitat identified as essential for western spiderwort at least 
every two years, and opportunistically in other years to allow for sampling across a variety of environmental gradients (e.g., wet and dry years).

4. Alberta Fish and Wildlife Division, Alberta Public Lands and Forests Division, or other agencies and researchers will develop best management practices (BMP's) for livestock grazing within spiderwort habitat. The intention is for these BMP's to be adopted by landholders. The Alberta Western Spiderwort Recovery Team recommends that this initiative be undertaken in year 2 and be updated as new information becomes available.

5. Alberta Fish and Wildlife Division, Alberta Public Lands and Forests Division, other agencies (Alberta Energy and Utilities Board) or researchers will develop BMP's for industrial development within or adjacent to western spiderwort habitat. The intention is for these BMP's to be adopted as standard protocol by industry stakeholders. The Alberta Western Spiderwort Recovery Team recommends that this initiative be undertaken in year 1 or 2 and be updated as new information becomes available.

6. Government agencies or non-government organizations will offer landowners and lessees with western spiderwort on their land a range/habitat management plan and range inventory of their land to determine how to incorporate BMP's for western spiderwort into their operations. The Alberta Western Spiderwort Recovery Team recommends that this initiative be undertaken in year 5 .

7. Government agencies or non-government organizations will assist landowners and lessees to manage their land in manner that sustains western spiderwort through the provision of various improvements as identified in the range/habitat management plans outline in point 6 above. The Alberta Western Spiderwort Recovery Team recommends that this initiative be undertaken in year 5 .

8. Alberta Fish and Wildlife Division will provide private landowners with information on conservation easements and other incentives for managing private land in a manner that is beneficial to western spiderwort and other listed species. The Alberta Western Spiderwort Recovery Team recommends that this initiative be undertaken in years 1 to 5 .

\section{$\underline{6.3 \text { Information and Education }}$}

1. Alberta Fish and Wildlife Division will update the current fact sheet on western spiderwort, as necessary. Fact sheets will be made available to the public and to interested stakeholders on the Alberta Species at Risk website and in hardcopy through the Alberta Sustainable Resource Development Information Centre.

2. Alberta Fish and Wildlife Division and/or Alberta Public Lands and Forests Division will provide information to any landholder or lessee that currently has or has the potential to have western spiderwort on their land with information on how to identify and conserve this species and its habitat (e.g., species fact sheets, BMP's etc.). The Alberta Western Spiderwort Recovery Team recommends that this initiative be undertaken in years 1 to 5 . 
3. Alberta Fish and Wildlife Division will make the recovery plan available to the public and interested stakeholders on the Alberta Species at Risk website and in hard copy through the Alberta Sustainable Resource Development Information Centre after the plan has received Ministerial approval. The Alberta Western Spiderwort Recovery Team recommends that this initiative be undertaken in year 1 .

\section{$\underline{6.4 \text { Research }}$}

1. Researchers from government agencies, non-government organizations, or universities will investigate the specific habitat requirements of this species, including the influence of varying levels of dune stabilization on western spiderwort to determine how tolerant it is to vegetation encroachment and whether life history of plants differs across habitat types. This information will be used to identify essential habitat for the species and to help manage its habitat. The Alberta Western Spiderwort Recovery Team recommends that this initiative be undertaken in years 2 to 4 .

2. Researchers from government agencies, non-government organizations, or universities will investigate the influence of precipitation on western spiderwort population dynamics (e.g., population fluctuations) and life history (seed set, germination success, etc.). The Alberta Western Spiderwort Recovery Team recommends that this initiative be undertaken in years 2 to 4 .

3. Researchers from government agencies, non-government organizations, or universities will conduct research to examine how different livestock grazing management strategies impact spiderwort, including how variation in the timing and duration of grazing influences flowering and seed set of western spiderwort and how variation in stocking rates affects sand dune stability. The Alberta Western Spiderwort Recovery Team recommends that this initiative be undertaken in years 2 to 4 .

4. Researchers from government agencies, non-government organizations, or universities will determine what species are pollinating western spiderwort and how varying levels of pollinators influence population dynamics of western spiderwort. The Alberta Western Spiderwort Recovery Team recommends that this initiative be undertaken in years 2 and 3

5. Researchers from government agencies, non-government organizations, or universities will investigate the role of the seed bank in maintaining this species, including the importance of the seedbank in maintaining this species during long periods of drought and how long seeds remain viable. The Alberta Western Spiderwort Recovery Team recommends that this initiative be undertaken in years 2 to 4 .

6. If deemed necessary, researchers from government agencies, non-government organizations, or universities should investigate the effects of invasive species on spiderwort and how different mitigation measures for invasive species may impact western spiderwort. The Alberta Western Spiderwort Recovery Team recommends that this initiative be undertaken on an as needed basis. 
7. Researchers from government agencies, non-government organizations, or universities will use genetic studies to determine the uniqueness of the Alberta western spiderwort population within the context of the overall Canadian population. The Alberta Western Spiderwort Recovery Team recommends that this initiative be undertaken in year 5 .

\subsection{Resource Acquisition}

1. Government agencies, non-government organizations, and researchers will annually approach government, non-government organizations, universities, industry, landowners and leaseholders to participate in or fund western spiderwort research and recovery initiatives.

\section{$\underline{6.6 \text { Legislation }}$}

1. The Alberta Western Spiderwort Recovery Team supports the development of regulations for the protection of endangered and threatened plants and their habitat and will review these guidelines after their development to determine if they adequately protect western spiderwort and its habitat while allowing for compatible land use activities such as livestock grazing.

\subsection{Plan Management and Administration}

1. Alberta Fish and Wildlife Division will convene the Alberta Western Spiderwort Recovery Team a minimum of once annually. At these meetings, the recovery team will review progress on implementation of the plan, review the effectiveness of recovery actions, and will develop new recovery actions, as required. The Chair of the recovery team will provide an annual report to the Director of Wildlife Management that details progress on implementation of the plan and any recommended changes to the plan.

2. All survey data should be submitted to ANHIC for incorporation into the database. ANHIC, in cooperation with other agencies and researchers, will enter all accumulated western spiderwort data into their database following each survey season.

3. The Chair of the Alberta Western Spiderwort Recovery Team, in association with Alberta Fish and Wildlife Division (Southeast Region), will ensure that all research activities are properly permitted and coordinated in order to maximize benefits from research and minimize disturbance to the population.

4. The Chair of the Alberta Western Spiderwort Recovery Team will communicate with other recovery teams, particularly those for other prairie plants or species associated with sandhills, to ensure that recovery actions for western spiderwort complement, whenever possible, recovery of other provincially or federally listed species at risk. 


\subsection{TIMETABLE FOR IMPLEMENTATION AND SCHEDULE OF COSTS}

The following schedule provides a timeline for implementation of activities identified by the Alberta Western Spiderwort Recovery Team as being important to the conservation of western spiderwort in Alberta, and provides an estimate of the costs associated with their implementation. It is anticipated that a variety of agencies will participate in the funding and implementation of these activities. Costs are not provided for activities that are part of the daily operations of the identified agencies (*). Costs associated with team members' expenses to attend recovery team meetings are also not included, but represent valued and necessary contributions associated with implementation of the recovery plan.

\begin{tabular}{|c|c|c|c|c|c|c|c|c|}
\hline \multirow{2}{*}{$\begin{array}{l}\text { Recovery } \\
\text { Plan } \\
\text { Section }\end{array}$} & \multirow{2}{*}{ Activity } & \multirow{2}{*}{$\begin{array}{c}\text { Lead } \\
\text { Agency }^{1}\end{array}$} & \multicolumn{5}{|c|}{ Cost (thousands/year) } & \multirow[b]{2}{*}{ Total } \\
\hline & & & 2005-06 & 2006-07 & 2007-08 & 2008-09 & 2009-10 & \\
\hline 6.1 & Population Management & & & & & & & \\
\hline \multirow{4}{*}{$\begin{array}{l}1 \\
2,3 \\
4\end{array}$} & \multirow{4}{*}{$\begin{array}{l}\text { Survey Protocol } \\
\text { Surveys } \\
\text { Control of Invasive Species }\end{array}$} & \multirow{4}{*}{$\begin{array}{l}\text { Various } \\
\text { Various } \\
\text { Various }\end{array}$} & 4 & & & & & 4 \\
\hline & & & & 10 & 10 & 10 & 10 & 40 \\
\hline & & & & * & * & 5 & 5 & 10 \\
\hline & & & 4 & 10 & 10 & 15 & 15 & 54 \\
\hline 6.2 & Habitat Management & & & & & & & \\
\hline \multirow{9}{*}{$\begin{array}{l}1 \\
2 \\
3 \\
4 \\
5 \\
6 \\
7 \\
8 \\
8\end{array}$} & \multirow{9}{*}{$\begin{array}{l}\text { Essential Habitat } \\
\text { Protective Notations } \\
\text { Habitat surveys } \\
\text { BMP's grazing } \\
\text { BMP's industrial } \\
\text { Range/habitat plans } \\
\text { Range improvements } \\
\text { Landowners Information }\end{array}$} & \multirow{9}{*}{$\begin{array}{l}\text { Various } \\
\text { FW, PL } \\
\text { Various } \\
\text { Various } \\
\text { Various } \\
\text { Various } \\
\text { Various } \\
\text { FW }\end{array}$} & & & 5 & & & 5 \\
\hline & & & * & * & * & * & * & \\
\hline & & & & 5 & & 5 & & 10 \\
\hline & & & & 2 & 2 & 2 & & 6 \\
\hline & & & & 2 & 2 & 2 & & 6 \\
\hline & & & & & & & 25 & 25 \\
\hline & & & & & & & 15 & 15 \\
\hline & & & * & * & * & * & * & \\
\hline & & & & 9 & 9 & 9 & 40 & 67 \\
\hline 6.3 & Education / Information & \multirow{5}{*}{$\begin{array}{l}\mathrm{FW} \\
\mathrm{FW} \\
\mathrm{FW}\end{array}$} & & & & & & \\
\hline \multirow{4}{*}{$\begin{array}{l}1 \\
2 \\
3\end{array}$} & \multirow{4}{*}{$\begin{array}{l}\text { Factsheet } \\
\text { Stakeholder Information } \\
\text { Website/Print Plan }\end{array}$} & & & & 1 & & 1 & 2 \\
\hline & & & * & * & * & * & * & \\
\hline & & & 5 & & & & & 5 \\
\hline & & & 5 & & 1 & & 1 & 7 \\
\hline 6.4 & Research & & & & & & & \\
\hline \multirow{8}{*}{$\begin{array}{l}1 \\
2 \\
3 \\
4 \\
5 \\
6 \\
7\end{array}$} & \multirow{8}{*}{$\begin{array}{l}\text { Habitat Requirements } \\
\text { Precipitation } \\
\text { Grazing Management } \\
\text { Pollinators } \\
\text { Seed bank } \\
\text { Invasive Species } \\
\text { Genetics }\end{array}$} & \multirow{8}{*}{$\begin{array}{l}\text { Various } \\
\text { Various } \\
\text { Various } \\
\text { Various } \\
\text { Various } \\
\text { Various } \\
\text { Various }\end{array}$} & & 20 & 20 & 20 & & 60 \\
\hline & & & & 5 & 5 & 5 & & 15 \\
\hline & & & & 5 & 5 & 5 & & 15 \\
\hline & & & & 10 & 10 & & & 20 \\
\hline & & & & 15 & 15 & 15 & & 45 \\
\hline & & & & & & 10 & 10 & 20 \\
\hline & & & & & & & 30 & 30 \\
\hline & & & & 55 & 55 & 55 & 40 & 205 \\
\hline 6.5 & Resource Acquisition & & & & & & & \\
\hline \multirow[t]{2}{*}{1} & \multirow{2}{*}{ Funding Securement } & \multirow{2}{*}{ Various } & * & * & * & * & * & 0 \\
\hline & & & & & & & & 0 \\
\hline 6.6 & Legislation & & & & & & & \\
\hline \multirow{2}{*}{ I } & \multirow{2}{*}{ Review Legislation } & \multirow[t]{2}{*}{ RT } & * & $*$ & * & * & * & 0 \\
\hline & & & & & & & & 0 \\
\hline 6.7 & Plan Management & & & & & & & \\
\hline 1 & Team Meetings/Report & FW & 1 & 1 & 1 & 1 & 1 & 5 \\
\hline 2 & Database Management & ANHIC & * & * & * & * & * & \\
\hline 3 & Research Coordination & FW & * & * & * & * & * & \\
\hline 4 & Liaison with other RT & FW & 0.5 & 0.5 & 0.5 & 0.5 & 0.5 & 2.5 \\
\hline & & & 1.5 & 1.5 & 1.5 & 1.5 & 1.5 & 7.5 \\
\hline & TOTAL & & & & & & & 340.5 \\
\hline
\end{tabular}

*Work included in other activities for this year. ${ }^{1}$ Lead Agency: Various indicates that a variety of agencies will lead implementation activities (see text), Alberta Fish and Wildlife Division (FW), Alberta Public Lands and Forests Division (PL), Alberta Natural Heritage Information Centre (ANHIC), Recovery Team (RT). 


\subsection{SOCIO-ECONOMIC CONSIDERATIONS}

The small area over which western spiderwort occurs should limit the potential socio-economic impacts of implementation of the recovery plan. The recovery plan recognizes the value of the landscape for activities such as grazing and industrial development. It is hoped that stakeholder involvement during the recovery process will help to minimize or mitigate costs associated with implementation of the plan. Potential economic costs could result from changes to grazing management. Costs could also result from restrictions on resource extraction or increased costs for extraction or development due to mitigation measures.

There are several social and economic benefits that may be realized from implementation of the recovery plan. There is the potential for leaseholders and landowners to realize increased productivity of their rangelands through range/habitat plans or through the provision of improvements for their operations. Economic benefits may also be realized through the proactive identification and control of invasive species before they expand throughout native rangelands. Activities that lead to the maintenance of an intact prairie landscape, may also lead to increased recreational opportunities, such as nature viewing, hunting, and ecotourism.

Western spiderwort is a unique prairie species and there is inherent value in keeping it on the landscape. Implementation of action items that conserve or improve the quality of native rangeland should lead to rangelands with high native biodiversity and should help conserve other species at risk on the prairies. Conservation of native prairie is also beneficial for continuing Alberta's heritage of ranching and ultimately contributes to maintaining clean air and water for society.

\subsection{PLAN REVIEW AND AMENDMENT}

The life of this plan is five years. The Alberta Western Spiderwort Recovery Team will conduct an annual review of the plan. The purpose of annual reviews is to monitor the implementation of the plan and to determine the effectiveness of recovery actions. The Chair of the recovery team will provide an annual report to the Director of Wildlife Management that details progress on implementation of the plan and any recommended changes to the plan. Recovery action plans are considered "living" documents and can be amended during these reviews. At the end of five years, the recovery team will meet again to determine whether any other amendments are required, prior to the plan being renewed for another five years. The team may determine that the existing recovery plan is suitable or is in need of revision. 


\subsection{LITERATURE CITED}

ANHIC. 2002. Dry Mixedgrass Subregion. Alberta. Natural Heritage Information Centre. URL: http://www.cd.gov.ab.ca/preserving/parks/anhic/drymixedgrass.asp

Coupland, R. T. 1987. Endangered prairie habitats: the mixed prairie. Pp. 35-41 In Proceedings of the Workshop on Endangered Species in the Prairie Provinces (G. L. Holroyd, W. B McGillivray, P. H. R. Stepney, D. M. Ealey, G. C. Trottier, and K. E. Eberhart, eds.). Provincial Museum of Alberta. Natural History Occasional Papers No. 9. Edmonton, AB. 367 pp.

COSEWIC 2002. COSEWIC assessment and update status report on the western spiderwort Tradescantia occidentalis in Canada. Committee on the Status of Endangered Wildlife in Canada. Ottawa. 25 pp.

COSEWIC. 2003. COSEWIC Assessment Results, November 2003. Committee on the Status of Endangered Wildlife in Canada. Ottawa. 44 pp.

Godwin, B. and J. Thorpe. 1991. Addendum to status report on western spiderwort. In Status Report on Western Spiderwort (Tradescantia occidentalis (Britt.) Smyth)) by B. Smith and C. Bradley. Committee on the Status of Endangered Wildlife in Canada.

Goulet, S. and N. Kenkel. 1997. Habitat survey and management proposal for Manitoba populations of western spiderwort (Tradescantia occidentalis). Department of Botany, University of Manitoba. Final Technical Report, World Wildlife Fund. 89 pp.

Hohn, S. 1994. Habitat requirements and management implications for western spiderwort (Tradescantia occidentalis). Critical Wildlife Habitat Program. Manitoba Department of Natural Resources, Wildlife Branch. 29 pp. plus tables.

Hrapko, J. O. 1989. Prairie spiderwort (Tradescantia occidentalis) in Alberta. Iris Newsletter $3: 3$.

Hughes, M. 2001. Summer 2001 field inventories of three nationally rare plants in Manitoba: small white ladyís-slipper, western spiderwort, and hairy prairie-clover. Canadian Wildlife Service, Environment Canada and Biodiversity Conservation Section, Wildlife Branch, Manitoba Conservation.

Jones, Jr., S. B. and A. E. Luchsinger. 1986. Plant Systematics. $2^{\text {nd }}$ ed. McGraw-Hill Inc., New York. $512 \mathrm{pp}$.

Kershaw, L., J. Gould, D. Johnson, and J. Lancaster (eds). 2001. Rare Vascular Plants of Alberta. The University of Alberta Press and the Canadian Forest Service, Edmonton, AB. 484 pp. 
Peters, S. 2003a. Inventory of western spiderwort (Tradescantia occidentalis) in Alberta, 2002. Alberta Sustainable Resource Development, Fish and Wildlife Division, Alberta Species at Risk Report No. 61. Edmonton, AB. 16 pp.

Peters, S. 2003b. Inventory of western spiderwort (Tradescantia occidentalis) in Alberta, 2003. Alberta Sustainable Resource Development, Fish and Wildlife Division, Addendum to Alberta Species at Risk Report No. 61. Edmonton, AB. 12 pp.

Smith B. 2001. Status of the western spiderwort (Tradescantia occidentalis) in Alberta, Alberta Environmental Protection, Fisheries and Wildlife Management Division, and Alberta Conservation Associations. Alberta Wildlife Status Report No. 31. Edmonton, AB. 12 pp.

Smith, B. 2002. Update COSEWIC status report on the western spiderwort Tradescantia occidentalis In COSEWIC assessment and update status report on the western spiderwort Tradescantia occidentalis in Canada. Committee of the Status of Endangered Wildlife in Canada. 25 pp.

Smith, B. and C. Bradley. 1992. COSEWIC status report on western spiderwort (Tradescantia occidentalis (Britt.) Smyth). Committee on the Status of Endangered Wildlife in Canada. $36 \mathrm{pp}$.

Wallis, C. and C. Wershler. 1988. Rare wildlife and plant conservation studies in sandhill and sand plain habitats of southern Alberta. Alberta Forestry, Lands and Wildlife, Edmonton, AB. Pub. No. T/176. $161 \mathrm{pp}$. 


\section{List of Titles in the Alberta Species at Risk Recovery Plan Series}

(As of December 2005)

No. 1 Maintenance and Recovery Plane for Western Blue Flag (Iris missouriensis) in Canada. (2002)

No. 3 Alberta Piping Plover Recovery Plane 2002-2004. (2002)

No. 3 Alberta Peregrine Falcon Recovery Plan 2004-2010 (2005)

No. 4 Alberta Woodland Caribou Recovery Plan 2004/05 - 2013/14 (2005)

No. 5 Recovery plan for Ord's kangaroo rat in Alberta (2005)

No. 6 Recovery plan for burrowing owl in Alberta (2005)

No. 7 Alberta northern leopard frog recovery plan, 2005-2010 (2005)

No. 8 Alberta greater sage-grouse recovery plan (2005)

No. 9 Maintenance and recovery plan for western spiderwort in Alberta 2005-2010 (2005) 







LIBRARY AND ARCHIVES CANADA

Bibliothèque et Archives Canada

3 3286535327957 